Research Article

Open Access

Inna Mysan

\title{
Theoretical Background and Methodology of Senior Preschoolers' Enlargement of the Vocabulary by Means of Phraseological Units
}

\author{
DOI 10.1515/sigtem-2016-0004
}

\begin{abstract}
The article deals with the problem of preschoolers' development of speech by means of phraseological units. It reveals their importance for children's mental development, in particular emphasises that the most striking verges of the child's language are reflected in its means of expression, that is, in phraseology. They make the language varied, expressive, emotional, vivid, figurative, deepen its ethno-cultural identity; offered are the results of the analysis of children's speech on listening and use of phraseological units in oral speech. By taking into account the data on specific features of perception, understanding and use of phraseological units in the statements of children are represented the methods of work on phraseology in kindergarten based on the following assumptions: on timely and methodically correct implementation of work on phraseological units will depend speech and mental development of the preschool children because at this age, they begin to comprehend figurative meanings of words and master the process of meanings changing. In addition, at this age period, the child's vocabulary is sufficiently formed to acquire the wealth and national characteristics of the native language, as well as expressive and aesthetic functions that perform phraseological units. Methodic contains and reveals its components such as: principles, goals, objectives, contents, methods, organisational forms and means of enlarging the vocabulary (impressive and expressive) with phraseological expressions.
\end{abstract}

Keywords: language development, phraseological units, figurative language, spoken language, phrase vocabulary, speech communication, language skills, phraseology perception, phraseology understanding, using of phraseology, figurative meaning of words.

\section{Introduction}

The most common, even we can say universal sphere of preschool children's communication is the construction, which corresponds to ordinary consciousness and everyday communication. Phraseological units (hereinafter - Ph. U.) make language material specific for this area of child's intercourse. They are inherent to spoken language, which to the great extent possess and use preschoolers. Therefore, the timely work on Ph. U. in kindergarten will naturally promote updating of speech listening skills and appropriate use of phraseology in statements of the preschool children.

What cause such close attention of child psychologists and specialists in lingvodidactics to work on phraseology?

First, $\mathrm{Ph}$. U. are the emotional and expressive means of language, embodying the wisdom of people, metaphorically reflect their history, traditions, quite correctly reflect people's attitudes towards moral and spiritual values, their relationships and observations of social phenomena and relationships of individuals, truthfully and critically reflect the lifestyles and experience of the ethnic group or the individual who

*Corresponding author: Inna Mysan: Pereyaslav-Khmelnytskyi State Pedagogical University named after Hryhoriy Skovoroda, Ukraine, E-mail: psycholing_lab@mail.ru 
discovers characterological personality traits, personal and mental characteristics. These one-piece constructions of phrasal type are condensed, summarise a certain content, opinion, concept, revealing the phenomena of objective reality in a variety of their essential characteristics.

Second, being in its majority the most person-oriented and having a figurative meaning, Ph. U. very delicately reproduce some specific negative traits of people, their life situations, giving them some definite evaluations, expressing the attitude of society towards them.

With its sophisticated humour, wit and superb visual parables, $\mathrm{Ph}$. U. are perceived by communicants, on address to which they are directed, without insults and personal humiliation. At the same time, such felicitous and figurative expressions as phraseological ones satisfy the claims of the speaker to utter in the most accurate, best, most clearly, understandable way comprehensively and completely. They have great expressive quality and deep potential opportunities; they improve the communication process, enriching it. Like deeply meaningful units, phraseological ones 'awaken speaker's opinion' as they represent by itself one of 'the highest concentrations of achievements of linguistic creativity' (Ващенко, 1989).

Third, capacity and concise of idiomatic expressions allow expressing the most complex meaning accurately and clearly. Their national identity and colouring promote the picturesque imagery and brightness to the speaker's statements. Wit and accuracy of Ph. U. allow them to be associated with emotional and expressive means of verbal communication. They can reproduce the noticed subtly and artfully expressed various nuances of human life.

Fourth, Ph. U. are instructive as they develop not only speech with the selected means, but also the mental experience of the child at whole, inspire reflection on the awareness and appreciation of human existence. Such felicitous and figurative expressions clearly interpret phenomena that surround us, the regularities of their development, put the important questions for understanding, reflection, enriching the sensual, cognitive, emotional and volitional mind of every child.

Finally, the utmost importance of phraseology for the development of preschoolers' speech is certified by the fact that in language, they are constantly operating side by side with separate words and make the functionally active portion of standardised literary language. So, Ph. U. are the expressive stereotypical means that do not require internal programming, since $\mathrm{Ph}$. U. are the stable combinations of two or more words, which, in the process of speaking, are reproduced as the ready verbal formula of semantic integrity (Ужченко, 2007). Therefore, they are economising means of communication.

Taking into consideration the above-mentioned opportunities of $\mathrm{Ph}$. U. in mental development of preschool children, author believes it necessary to begin shaping the language skills of listening and use by children in their statements phraseology, from the pre-school age.

\section{The Aim of the Study}

To highlight the formation of speech skills for understanding and use of phraseological expressions in utterances of preschoolers and methods of work aimed at enlargement of their language phraseology.

\section{Materials and Methods}

Studying the feasibility of kindergarten work on phraseology, author used authentic materials of speech analysis of the preschool children, which provided determination of their ability to understand and use in the statements of Ph. U. by means of methods: analysis of children's expression, observation of their speech, interviews with children and parents, specific questions on the content of phraseology, classification of phraseology, used by children in games, everyday communication, in monological speech, during teamwork, etc., encouraging children to explain the meaning of the phraseology - author found difficulties that children experience during perception and understanding the phraseology and their actualisation in speech communication. In addition, author conducted questioning of kindergarten teachers and parents, talked with them, studied the experience of kindergarten teachers on phraseologies, analysed 
scientific works and researches of psychologists and specialists in lingvodidactics on the problems of teaching children phraseology, integrated the best teaching ideas for the development of speech abilities of children by means of phraseology into created method, developed the didactic model of children's speech enrichment by $\mathrm{Ph}$. U.

\section{Results}

Speech analysis was carried out according to the following criteria and indicators:

1. the cognitive criterion and the corresponding parameters: a ) understanding of the direct meaning of $\mathrm{Ph}$. U. words-components; b ) understanding of $\mathrm{Ph}$. U. figurative meaning; c) conceptuality;

2. the pragmatic criterion and the corresponding indicators: a) the appropriateness of the use in speech; b) the accuracy of reproduction; c) the frequency of Ph. U. use;

3. expressive-stylistic criterion and the corresponding parameters: a ) expressiveness, b) emotionality, c) evaluation.

In psycholinguistic experiment for preschoolers' perception were proposed Ukrainian $\mathrm{Ph}$. U., such as: 'За холодну воду не братися', 'Залити за шкуру сала', 'Моя хата скраю', ‘3 курями лягати спати', 'Кривити душею' and others. The children had to explain how they understand these phrases.

The correct answers of senior preschoolers were considered those ones in which: a) was given, for instance, a description of phraseologism 'prevaricate - to cheat, to lie', 'to go to sleep with chickens - too early', and b) was selected a suitable synonym: 'to catch the crow - to dawdle', c) phraseological unit was deformed or replaced by one of its words: 'In the field, the wind can not be caught', 'Disservice - clumsy service'.

Other responses were classified as false. Among misinterpreted, author found the replacement of:

a) figurative meaning by a direct one: 'Залити сала за шкуру' (Pour the fat from the skin - it should be finely chopped the bacon for nothing left of it), 'Не торкатися за холодну воду' (Not to touch the cold water - the water is cold and you can not tackle, but only drink), '3 відкритим обличчям' (With open face - there is nothing on the face);

b) $\mathrm{Ph}$. U. by contextual synonymous with inaccurate figurative meaning: 'Задирати носа' (To turn up the nose - to count the crows); c) phraseological unit from another synonymic line 'Ловити гав' (То catch the crow - to dawdle) - as well as a tautology, and violation of phraseological unit's structure: 'Золота осінь - Осінь в золоті' (Golden autumn - autumn in gold).

Mistaken author considered also different semantic distortion on the base of random associations: 'Комар носа не підточить' (Mosquito does not undermine his nose - mosquito save his nose; to do something not good) - and incorrect answers, not connected with both direct and figurative sense of phraseology: 'Моя хата скраю' (My house is at the end - to deceive, a person who has nothing).

Author found that the number of attempts to explain every suggested to children phraseological unit was greater than the number of refusals. There was also the important fact fixed: on the base of understanding by preschoolers the meaning of separate words, included into $\mathrm{Ph}$. U., they have an illusion only in understanding of phraseological expressions. They tried to bring the value of phraseological expressions only with the meanings of words, of which it is composed. At the same time, the preschoolers were not aware that certain words of phraseological expressions are only the parts of figurative meaning. The study also found that children under the school age are able to understand the figurative meaning of certain $\mathrm{Ph}$. U., reflecting different aspects of their life.

Observations on senior preschoolers' speech have given us such an opportunity to fix such a tendency: they very rarely use $\mathrm{Ph}$. U. in the process of communication. Basically, children use them in the plot and role-playing games, repeat set expressions heard from their parents and address to them, for example, 'Пасти задніх' (Left behind), 'Тримати язик за зубами” (Keep silent), 'Крутитися як білка в колесі' (Twisted like squirrel in the wheel).

Author recorded the usage (but not always appropriate) of Ph. U. in the intercourse: 'Як кіт наплакав" (Like cat cried), 'Яблуку ніде впасти' (There is no room for apple to fall), 'Язик без кісток' (Boneless tongue), in composing creative stories and tales. 
The preschoolers also use Ph. U. in execution of labor instructions and collective work 'Бити байдики' (To twiddle), 'Задерти носа' (Turn up the nose), 'Комар носа не підточить' (Mosquito does not undermine his nose), 'Майстер на всі руки' (Jack of all trades).

Extremely rare the use of phraseology in the speech of children can be explained by the fact that 'in the process of learning, the children sustain too much impact of scientific and business language, so on the employments the expressions which characterise the everyday speech, they perceive as inappropriate. It scarcely needs the proof that it affects the speech of children negatively (Алексеева, Яшина , 1998, 10). The reason that they do not take in their speech Ph. U., lies in the fact that they were not taught to understand and use this stable word combination in communication. This lack of expression bereave the appropriate imagery, expressiveness, variable means necessary to clarify the characteristics and properties of objects, events and actions, characteristics of situations. Children's ignorance of phraseological means complicate the process of communicative interaction as well as the construction of various types of sentences.

In addition to interviews with caregivers, author found their view on the role of work on phraseology in kindergarten. Author got the responses that coincide with the views of scholars about the importance of phraseology in the development of children: 'For a comprehensive language development of children', 'For concreteness, emotional expressiveness of speech'.

The question 'What significance have Ph. U. in preschool child's development?' the caregivers answered as follows:

- They develop their imagination and thinking, the ability to compare something',

- Enrich the Ukrainian language and provide some shades of speech',

- The vocabulary enlargement of children, significative development, concreteness of speech take place there',

- They expand their understanding of the material and spiritual culture of Ukrainian people',

- They are favourable for children's memory and attention',

- 'They develop children's interest in unfamiliar words',

- 'They are important for the expression of their own thoughts, impressions, experience'.

These facts indicate the need for improvement of methodic work with speech enrichment by means of imagery that is phraseology.

To this end, author has created a method of enriching the children's speech by means of phraseological units. Work on the phraseology, author conducted in kindergarten in terms of listening and speaking, and working procedure over idiomatic expressions contained the following interrelated parts: principles, purpose, objectives, contents, methods, organisational forms and means.

Important lingvodidactic principles of work on phraseology, author considers the following:

1. figurative expressions found in literature appear in children's speech without teacher's interference when their sense is well-learned, which may be achieved by multiple reading and analysis of the work (Vodovozova, Водовозова, 1876. Умственное развитие детей от первого проявления сознания до 8-летнего возраста. СПб. (in Russian));

2. not knowing two or three words in a sentence, a child can understand the subtle shade of opinion from the general meaning of speech;

3. it is necessary to memorise the beautiful examples of living folk speech while reading a book, and not retelling it;

4. the teacher's speech should be, if possible, alive, imaginative and contain popular expressions (Tiheyeva, Тихеєва, 1981. Развитие речи детей. Москва: Просвещение. (in Russian));

5. it is impractical to introduce a large number of new vocabulary into children's speech. The literature should be selected on the degree of vocabulary complexity of the literary works (Fliorina, Фльорина, 1961. Эстетическое воспитание дошкольника. Москва: Изд-во Академии педагогических наук РСФСР. (in Russian));

6. the figurative expressions are learning by children during their acquaintance with folktales;

7. mastering of proverbs, sayings, epithets, felicitous expressions facilitate their use by an educator in 
the appropriate situations in a way the child can capture the relationship of these turns of speech in accordance with his actions;

8. the children should not be required in any case to use the figurative expressions in their speech or learn them by heart (Ushakova, Ушакова, 1994. Программа развития речи детей дошкольного возраста в детском саду. Москва: РАO. (in Russian)).

The objective of the work on phraseology in kindergarten author sees in enriching children's speech by set expressions - Ph. U. through the development of their speech skills of listening and speaking, and at the same time the tasks are the next:

1. to help the children to understand the figurative meanings of words, to master the meaning transference, which occurs during the perception of Ph. U.;

2. to form in children a strong interest to percept idiomatic phrases which are unusual for them language means;

3. to enlarge children's active vocabulary by $\mathrm{Ph}$. U.;

4. to form in preschoolers skills to use appropriately the phraseology in different communicative situations.

During the preschool children's training of phraseology author focuses attention on developing of their sense of language and shaping the ability to differentiate $\mathrm{Ph}$. U. from regular expressions, to achieve realizing of their meaning, understanding of the stylistic role in expressions and gradually enrichment of preschoolers' phrase vocabulary, developing the skills to use it.

An important task for educator is, author believes, to prevent in children's speech vulgarisation of their idiomatic vocabulary, because the steady turns provide high charge of human emotions: affection, tenderness, compassion, joy, censure, reproach and so on.

Content of the work on phraseology is presented in author's methodic by vocabulary-minimum, containing Ph. U. available for understanding and use of children in their speech (according to the analysis of children's speech).

Author concluded the dictionary, which contains $\mathrm{Ph}$. U. for pre-school children, created on the basis of their potential opportunities to use phraseology in different communicative situations, games, joint work, employments, walks, entertainments and so on.

Principles of phraseology selection that the author followed in creating the dictionary correspond to the regulations on elaboration the dictionary for preschoolers. These regulations are formulated by wellknown psychologists and specialists in lingvodidactics: N. V. Havrysh (Гавриш, 2002)), A. P. Ivanenko (Іваненко, 2005)), L. A. Kalmykova (Калмикова, 2008)), Yu. S. Lyahovska (Ляховська, 1968)), А. S. Ushakova (Ушакова, 1994)), V. I. Yashyna (Яшина, 1998)) etc.

In modern conditions, extremely important role has the use in educational process of phraseologisms with ethno-cultural content, because they assist expressing the beauty and wealth of the native language and have informative and educational value.

To author's opinion, the effective methods of work on Ph. U. listening, which help to make sense of their value, run the beauty of external forms and provide rejection from the literal meaning of phraseological word-combinations are the next:

a) specific questions for understanding of their figurative meaning;

b) an explanation of unknown words (phraseologisms) or phrase through the text and context;

c) introduction with works of small folk forms (proverbs, sayings, riddles) and phraseologisms;

d) clarification of figurative expression by contextual synonyms; e) explanation of figurative expressions before reading a text, etc.

Best practices that promote the development of skills appropriate for using phraseology in speech, author considers the following:

a) learning the figurative expressions by heart;

b) intensified articulation, intonational separation of phraseologism, repetition (repeating after the sample);

c) selection of phraseologisms in order to characterise the novel characters and personages of stories, events, etc. 
Like all work over the word, phraseological exercises, games, employments as forms of work aimed at enlargement and enrichment of children's vocabulary, disclosure of words meanings, development of skills to use correctly the common phraseology in speech utterance in order to give them greater precision and expressiveness.

In senior preschoolers' groups were used primarily such types of exercises:

5. on explanation of phraseological meaning;

6. on the development of creative thinking;

7. on synonymous translation as a way of understanding the content of Ph. U.;

8. on conducting in oral form the group idiomatic vocabulary;

9. on basic etymological analysis.

The most useful, as author thinks, are the following phraseological tasks and exercises: making sentences with phraseologisms and short stories by them, synonymous substitution of set expressions by words and sentences, teaching vocabulary games ('Quickly find and explain', 'Idiomatic domino', 'Language bingo', 'Who would call more unusual expressions?', 'Tell me differently', I'll say and you continue' and so on).

To the means of work with phraseology author includes: visibility, fictions, stories from the life of children, small folk genres, putting ups, folk tales, folk bywords, proverbs, sayings, picturesque speech of adults, declamation, riddles, poems, etc., which contain phraseological turns. By means of this technique are used Ph. U.

\section{Conclusions}

Systems approach to the unity of all components (principles, goals, objectives, content, forms, methods, tools) in creating the method of forming preschoolers' speech skills by means of phraseology promotes the development of accurate and concise, expressive and imaginative expression of their opinion. At the same time, phraseological work on the employments in kindergarten deepens the interest of preschoolers to learning the language and oral traditions of the Ukrainian people, reading of literary works, provides linguistic identity.

Problems for discussion, in author's opinion, may be the following:

- Which principles should be laid into the basis for the creation of dictionaries-minimums for preschoolers?

- How to explain better the figurative meaning of $\mathrm{Ph}$. U.?

- Could the children learn the value of Ph. U. without adults' assistance?

- Which idiomatic expressions should not be offered for pre-school children in the process of learning?

\section{References}

Алексеева, М. М., Яшина, В. И. (1998). Методика развития речи и обучения родному языку дошкольников: учеб. пособие для студ. высш. и сред. пед. учеб. заведений [Methodics of speech development and teaching preschoolers native language]. М. М. Алексеева, , 2-е изд., испр. Москва: Изд-ий центр Академия. (in Russian)

Ващенко, В. С. (1989). Фрагменти з українського мовознавства: Пропедевтичний посібник молодого науковця. [Fragments from Ukrainian linguistics. Propedeutic textbook of young scientist]. Дніпропетровськ: ДДУ. (in Ukrainian)

Водовозова, Е. Н. (1876). Умственное развитие детей от первого проявления сознания до 8-летнего возраста. [Mental development from the first appearing of consciousness up to the third year of life]. СПб. (in Russian)

Гавриш, Н. В. (1991). Формирование образности речи старших дошкольников в прочессе обучения родному языку: Дисс. ... канд. пед. наук. [Formation of senior preschoolers' imagenary speech in the process of native languagee taching]. Москва. (in Russian)

Іваненко, А. П. (2005). Теоретичні засади словникової роботи з дітьми молодшого дошкільного віку // Дошкільна лінгводидактика. Хрестоматія. Навчальний посібник для студентів вищих педагогічних навчальних закладів; упорядник А.М. Богуш. [Theoretical bases of work on vocabulary with children of younger preschool age]. Ч. I-II. Київ. Видавничий Дім «Слово». (in Ukrainian)

Калмикова, Л. О. (2008). Психологія формування мовленнєвої діяльності у дітей дошкільного віку: монографія. [Psychology of speech activity formation in children of a preschool age ]. Київ. Фенікс. (in Ukrainian) 
Ляховская, Ю. С. (1968). Активизачия словаря детей старшего дошкольного возраста: Дисс. ... канд. пед. наук. [Activization of the senior preschool age children's vocabulary]. Москва. (in Russian)

Тихеева, Е. И. (1981). Развитие речи детей. [Development of children's speech]. Москва: Просвещение. (in Russian)

Ужченко, В. Д. (2007). Фразеологія сучасної української мови: Навч. посіб. [Phraseology of modern Ukrainian language]. Київ: Знання. (in Ukrainian)

Флерина, Е. А. (1961). Эстетическое воспитание дошкольника. [Aethetic education of preschooler]. Москва: Изд-во Академии педагогических наук РСФСР. (in Russian)

Ушакова, О. С. (1994). Программа развития речи детей дошкольного возраста в детском саду. [Program of preschoolers' development of speech in kindergarten]. Москва: PAO. (in Russian) 